DOI: $10.14746 /$ por.2019.1.6

\title{
GONZO UWIKŁANE, PRZEMOC PRZEDSTAWIENIA ORAZ MOZAIKA FANTAZMATÓW NARODOWYCH, CZYLI O „UKRAIŃSKIEJ TRYLOGII" ZIEMOWITA SZCZERKA
}

\author{
RYSZARD KuPIDURA ${ }^{1}$ \\ (Uniwersytet im. Adama Mickiewicza w Poznaniu)
}

Słowa kluczowe: Ziemowit Szczerek, postkolonializm, gonzo, imagologia, literatura polska, Ukraina

Keywords: Ziemowit Szczerek, postcolonialism, gonzo, imagology, Polish literature, Ukraine

\begin{abstract}
Abstrakt: Ryszard Kupidura, GONZO UWIKŁANE, PRZEMOC PRZEDSTAWIENIA ORAZ MOZAIKA FANTAZMATÓW NARODOWYCH, CZYLI O „UKRAIŃSKIEJ TRYLOGII” ZIEMOWITA SZCZERKA. „PORÓWNANIA” 1 (24), 2019. T. XXIV, S. 55-67. ISSN 1733-165X. Celem niniejszego tekstu jest analiza trzech książek Ziemowita Szczerka: Przyjdzie Mordor i nas zje (2013), Tatuażu z tryzubem (2015) oraz Międzymorza (2017), które ze względu na obecność w nich tematów związanych ze wschodnim sąsiadem Polski autor artykułu łączy umownie w „ukraińską trylogię". Wśród podjętych w tekście problemów badawczych znalazły się m.in.: kwestia genologicznego statusu twórczości Szczerka, pytania o implikacje, które niesie za sobą pisanie reportaży na temat kraju o wieloletniej i złożonej historii stosunków kolonialnych z krajem, z którego pochodzi sam pisarz, czy wreszcie próba spojrzenia na ukraińską sytuację z ponadregionalnej perspektywy.
\end{abstract}

Abstract: Ryszard Kupidura, ENTANGLED GONZO, VIOLENCE OF REPRESENTATION AND A MOSAIC OF NATIONAL FANTASIES, OR ABOUT THE “UKRAINIAN TRILOGY” BY ZIEMOWIT SZCZEREK. "PORÓWNANIA" 1 (24), 2019. Vol. XXIV, P. 55-67. ISSN 1733-165X. The aim of this paper is the analysis of three books by Ziemowit Szczerek: Mordor will come and eat us (2013), Tattoo with tryzub (2015) and Intermarium (2017), which due to the presence of topics related to the eastern neighbor of Poland, the author of the article combines in a "Ukrainian trilogy". The problems addressed in the text include among others: the issue of genre status of Szczerek's

1 E-mail: ryszardk@amu.edu.pl 
oeuvre; questions about implications of writing about the country with postcolonial status and an attempt to approach the Ukrainian situation from a supra-regional perspective.

Szereg problemów, które znany ukraiński pisarz Jurij Andruchowycz podjął w trylogii Rekreacje (1992), Moskoviada (1993) oraz Perwersja (1996), odnosi się w głównej mierze do postkolonialnej kondycji naszego wschodniego sąsiada na progu uzyskania niepodległości. Każdy z tekstów stawał się w swoim czasie przyczynkiem do dyskusji nad niejednoznacznością emancypacji, wewnętrznymi transgresjami, relacjami z (post)hegemonem, a w przypadku ostatniej książki stwarzał warunki do ujrzenia ukraińskiej sytuacji w ponadregionalnej perspektywie i wpisania jej w szerszy, europejski kontekst. Kompleks powyższych zagadnień scala oraz wyodrębnia wspomniane powieści z całego dorobku prozatorskiego Andruchowycza i powoduje, że w literaturze przedmiotu upowszechnił się ich status właśnie $\mathrm{w}$ postaci trylogii, ze względu na postmodernistyczną poetykę nazywaną często karnawałową.

Zaczynam od wzmianki o twórczości ukraińskiego pisarza, gdyż zaczerpnięta z niej problematyka może posłużyć jako swego rodzaju algorytm ekstrakcji ukraińskich wątków z reporterskiego dorobku Ziemowita Szczerka, który od kilku lat należy do czołówki polskich pisarzy młodej generacji oraz pozostaje aktywnym uczestnikiem debaty społecznej w Polsce ${ }^{2}$. Ukraińskie motywy zawarte w Przyjdzie Mordor i nas zje (2013), Międzymorzu (2017), przede wszystkim zaś w Tatuażu z tryzubem (2015) poprzez to, że odnoszą się do podobnego jak u Andruchowycza zespołu problemów, pozwalają na umowne uszeregowanie tych pozycji w anonsowaną w tytule artykułu „ukraińską trylogię”. Warto też zaznaczyć, że Szczerek to również uważny czytelnik autora Moscoviady, deklarujący zarówno w swoich tekstach, jak i w wywiadach, że wśród lektur, które formowały jego światopogląd, powieści Andruchowycza zajmują niepoślednie miejsce (Szczerek 2015: 140-144; Janiec-Nyitrai 129). Nie dziwi zatem, że postkolonialna aura, tak bardzo obecna w literaturze lat dziewięćdziesiątych XX wieku na Ukrainie, wciąż jeszcze odczuwalna jest w tekstach piszącego ponad dwie dekady później polskiego autora. Nie zmienia

2 Zwróćmy uwagę, że sposób funkcjonowania Szczerka jako pisarza przypomina model ukraiński. Wysoka aktywność w mediach społecznościowych, polegająca na komentowaniu bieżących wydarzeń społecznych, deklarowaniu swoich poglądów politycznych, publikowaniu fragmentów twórczości czy nawet tworzeniu autorskich memów, jest formą kontaktu z publicznością stosowaną przez dziesiątki ukraińskich pisarzy należących do różnych pokoleń literackich (wymieńmy chociażby Artema Poleżakę, Jurija Wynnyczuka, Andrija Lubkę, Andrija Bondara, Hrihorija Semenczuka, Ołeksandra Irwańca, Switłanę Powaliajewą i wielu innych). W Polsce podobny model praktycznie się nie przyjął, czego nie zmieniły nawet ostatnie lata, które przyniosły zaostrzenie walki politycznej i pogłębioną polaryzację polskiego społeczeństwa. Trudno ocenić, czy na postawę Szczerka wpłynęły wieloletnie kontakty z ukraińskimi środowiskami twórczymi, czy jest to raczej zbieżność przypadkowa. W każdym razie sięganie przez Szczerka po podobne formy reagowania na zmieniającą się rzeczywistość społeczno-polityczną może być potraktowane jako jedna z kilku zapewne odpowiedzi na pytanie o źródła empatii pisarza w stosunku do ukraińskiej sytuacji. 
tego nawet fakt, że Szczerek skłania się ku odmiennym niż Andruchowycz gatunkom literackim oraz że stosuje inne niż w przypadku postmodernistycznej poetyki środki wyrazu artystycznego.

\section{Gonzo - gatunek uwikłany}

Przyjdzie Mordor i nas zje to książka, która ugruntowała miejsce Szczerka na polskiej scenie literackiej. Jej sukces może być mierzony nie tylko ważnymi wyróżnieniami (Paszport „Polityki” 2013, nominacja do Nagrody Nike 2014), ale także licznymi wypowiedziami krytyków i badaczy literatury. Od czasu ukazania się utworu w 2013 roku do chwili obecnej nie milknie dyskusja nad jej zróżnicowaną problematyką dotyczącą między innymi dekonstrukcji mitów narodowych (zarówno współczesnych, jak i tych o kresowej proweniencji), polskich odruchów neokolonialnych, kondycji człowieka w sytuacji posttotalitarnej, stosunku centrum wobec peryferii, uwarunkowań turystyki alternatywnej (szczególnie w odmianie tzw. poverty tourism), a także całego kompleksu zagadnień genologicznych, dotyczących transmisji Nowego Dziennikarstwa na polski grunt. W wypowiedziach Przemysława Czaplińskiego, Elżbiety Rybickiej, Izabelli Adamczewskiej, Arkadiusza Kalina, Edyty Żyrek-Horodyskiej, Agnieszki Janiec-Nyitrai, Joanny Szydłowskiej, Marty Cobel-Tokarskiej, Urszuli Pieczek, Iwony Boruszkowskiej, Romana Kabaczija, Anastasii Łewkowej, Justyny E. Dąbrowskiej i innych większość z powyższych problemów została już rozpoznana i wyczerpująco omówiona, nie ma zatem potrzeby powtórnego rozprawiania o nich. Swój głos w dyskusji chciałbym zawrzeć jedynie $\mathrm{w}$ dwóch spostrzeżeniach. Po pierwsze, przegląd literatury przedmiotu daje sprzeczne odpowiedzi dotyczące klasyfikacji gatunkowej tego utworu. Nie chodzi tutaj o mało produktywne moim zdaniem rozstrzyganie, czy mamy do czynienia w tym przypadku z powieścią drogi, czy raczej z literaturą podróżniczą. O wiele ciekawsza wydaje się odpowiedź na pytanie, czy i w jakim stopniu Szczerek realizuje postulaty dziennikarstwa gonzo oraz jaką funkcję pełni umieszczony w środku książki autotematyczny rozdział o tym samym tytule. Adamczewska w swoim opartym na bogatej bibliografii studium na temat historii gonzo podaje jego definicję jako stylu dziennikarskiego, który charakteryzuje

skrajny subiektywizm, luźne podejście do faktów i językowa hiperbola. Głównym bohaterem tekstu jest jego autor, osią fabularną - przygody o awanturniczym charakterze [...]. Uczestnictwo, a niekiedy prowokowanie samych zdarzeń rozmywa granice pomiędzy podmiotem a przedmiotem narracji (Adamczewska 187-188).

To są pryncypia klasycznego gonzo, którego twórcą jest Hunter S. Thompson, autor Lęku i odrazy w Las Vegas. Z książką amerykańskiego pisarza Przyjdzie Mor- 
dor ... ma rzeczywiście wiele wspólnego, jednak nie tak dużo, jak się pozornie wydaje. We wspomnianym autotematycznym rozdziale Szczerek opisuje postać gonzo, w której - trochę na zasadzie travelling theory - dotarł on do Polski:

Zawodowo zająłem się ściemnianiem [...]. Wystarczyło, bym pisał kilka tekstów na temat Ukrainy utrzymanych $\mathrm{w}$ tonie gonzo a już miałem zlecenia. Epatowałem $\mathrm{w}$ tych tekstach ukraińskim rozdupczeniem i rozwłóczeniem. Musiało być brudno, mocno i okrutnie. Taka jest istota gonzo. W gonzo jest gorzała, są szlugi, są dragi, są panienki. Są wulgaryzmy (Szczerek 2013: 99).

Ten sam fragment cytuje Adamczewska i pisze, że "tak rozumiany styl gonzo realizowany jest w tekście" (Adamczewska 190). Takie rozpoznanie musi budzić wątpliwość, tym bardziej że by poprzeć swe stanowisko, badaczka w dalszym fragmencie tekstu dokonuje redukcji osobowości narratora, który ma być jedynie „złośliwy i politycznie niepoprawny” (Adamczewska 190). Stoi to w sprzeczności ze stanowiskiem Czaplińskiego, który pisze, że „najważniejsze przygody opisane w książce nie dotyczą hardcorowych przeżyć w barze czy w stepie, lecz przemian sposobu myślenia" (Ziemowit Szczerek, źródło elektroniczne). Pozycjonowanie Przyjdzie Mordor... jako reportainment (Adamczewska 196) mogłoby tłumaczyć sukces czytelniczy, nie tłumaczy jednak wzmożonej atencji badaczy. Nie wyjaśnia też, dlaczego sam autor, wprowadzając autotematyczny rozdział, zachowuje się niczym magik Karola Irzykowskiego, który organizuje ostatnie przedstawienie, by odsłonić swój warsztat (Bakuła 69). Z punktu widzenia korzyści marketingowych byłoby to przecież całkowicie nieuzasadnione. Sam pisarz w wywiadach odżegnuje się od utożsamiania jego powieści z gonzo (co naturalnie nie jest sądem rozstrzygającym): "Przyjdzie Mordor i nas zje nie było pisane jako gonzo, było pisane raczej jako gonzo na temat gonzo" (cyt. za: Kalin 78). Jeszcze bardziej przekonująca wydaje się sugestia, że powieść można potraktować jako próbę spojrzenia na gonzo z dystansu oraz próbę ustalenia ceny, którą trzeba zapłacić za przyciągnięcie uwagi współczesnego czytelnika (Żyrek-Horodyska 230). Zwróćmy uwagę, że w książce narrator Łukasz Ponczyński jedynie wspomina o napisanych wcześniej gonzo-artykułach dla portali internetowych. Są one więc wzmiankowane, ale w tekście nie wybrzmiewają i ostatecznie pozostają $\mathrm{w}$ stanie in potentia. Na przykładzie swojego bohatera Szczerek pokazuje, że wyrosłe z etosu Nowego Dziennikarstwa gonzo potrafi obecnie zaspokajać jedynie niskie potrzeby hardcore'u lub Schadenfreude, co w konsekwencji prowadzi do generowania postaw o charakterze neokolonialnym. Uświadamia to sobie sam Ponczyński, którego relacja nabiera cech spowiedzi łże-reportażysty. Tym samym gonzo można rozumieć również jako postawę etyczną. Reporterskie gonzo zaś to środowisko, w którym stereotypy czy, mówiąc precyzyjniej, aktywizujące mechanizmy stereotypizacji obrazy literackie, mają się nadzwyczaj dobrze i mnożą się bez większych przeszkód ze strony autora. Tak jak upojenie narkotyczne pozor- 
nie poszerza świadomość człowieka, tak uleganie pokusie gonzo ${ }^{3}$ pozornie zwiększa swobodę dziennikarza, który ostatecznie gubi jednak z oczu bohatera swego wiecznie niezrealizowanego reportażu. Hardcore traci swój sztafażowy charakter i staje się centralnym tematem. Realizacja projektu gorzała-szlugi-dragi-panienki immanentnie zawiera w sobie figurę milczącego subalterna, który w finale sprząta po libacji (siłą rzeczy przypomina się scena z poniżoną pokojówką z Lęku i odrazy Thompsona). Jeżeli w dodatku bachanalia odbywają się na terytorium Innego, dochodzi do tego komponent napięcia międzyetnicznego. Tymczasem Mordor ... pełen jest wypowiedzi ukraińskich postsubalternów, które zakłócają ów hardcorowy błogostan:

To ja ci powiem dlaczego tu przyjeżdżacie. Przyjeżdżacie tutaj, bo w innych krajach się $\mathrm{z}$ was śmieją. I mają was za to, za co wy nas macie: za zacofane zadupie, z którego się można ponabijać. I wobec którego można poczuć wyższość (Szczerek 2013: 37).

Szczerek rzeczywiście zachowuje się jak magik, który demaskuje swoje triki $\mathrm{w}$ ostatnim przedstawieniu. W kolejnych swoich książkach nie wyrzeka się wprawdzie subiektywizmu ani hiperboli językowych, jednak odchodzi od gonzo, przestaje eksponować osobę autora/narratora, a w miejsce awanturniczych przygód wkraczają w jego tekstach eseistyczne refleksje dotyczące historii opisywanego regionu.

Przyjdzie Mordor... to dotychczas jedyna z trzech omawianych w niniejszym tekście książek, która została przetłumaczona na język ukraiński ${ }^{4}$. Warto zaznaczyć, że ukraińskie wydanie z 2014 roku w tłumaczeniu Andrija Bondara nie spotkało się z szerszą recepcją na samej Ukrainie. Poza omówieniami książki na literackich portalach internetowych autorstwa A. Łewkowej i R. Kabaczija na próżno szukać wypowiedzi badaczy, wpisujących tekst Szczerka w szerszy polsko-ukraiński kontekst. Wydaje się, że pominięcie (choć raczej nie przemilczenie) tej książki w ukraińskiej debacie intelektualnej jest symptomatyczne przynajmniej z kilku powodów. Z jednej strony można przyjąć, że ukraińskie wydanie Mordoru... ukazało się w 2014 roku, a więc w dobie rewolucji godności i początku rosyjskiej agresji na Ukrainie, kiedy siłą rzeczy uwaga intelektualistów była skupiona na innych problemach. Jednak na swój sposób i ten fakt staje się symptomatyczny, gdyż permanentną cechą polsko-ukraińskiego dialogu po 1991 roku jest rzekomy brak odpowiedniego momentu na dyskusję o ważnych i trudnych dla obu partnerów sprawach. Polsko-ukraiński dialog funkcjonuje niejako w ciągłym „nie teraz”. Dodatkowo trzeba zauważyć, że polska tematyka do niedawna była mało obecna w ukraińskim dyskursie publicznym, akademickim, a także w twórczości literackiej i praktykach artystycznych

3 „Skłonność" do gonzo Adamczewska trafnie demaskuje w reportażach Jacka Hugo-Badera (Adamczewska 191).

4 Oprócz niej w 2016 roku w tym samym wydawnictwie ukazało się tłumaczenie Siódemki. 
(tutaj symbolicznego wymiaru może nabrać polska nieobecność we wspomnianej trylogii Andruchowycza), co wpisuje się w szereg zaniedbań, skutkujących przykrymi konsekwencjami, które możemy obserwować w ostatnim czasie, kiedy dialog z ciągłego „nie teraz” płynnie przeszedł w „za późno". Tym samym przedstawione w samym tekście Mordoru... wariacje możliwych ukraińskich odpowiedzi pozostają jedynie autorską imaginacją, czy - inaczej mówiąc - imitacją poglądów Innego (Orekhov 99). Można też powiedzieć, że Szczerek sam ulega polskiemu metastereotypowi, zawierającemu się w przekonaniu, że relacje z polskością zajmują centralne miejsce w ukraińskiej świadomości kolektywnej.

\section{Ciuciubabka z krytykiem postkolonialnym}

Omawiając relacje z podróży Antoniego Słonimskiego i Jacka Hugo-Badera do Związku Sowieckiego oraz Rosji, Hanna Gosk pisze, że przedstawna okoliczność polegająca na tym, że autorzy ci większą część swojego życia spędzili na ziemiach polskich całkowicie lub częściowo zależnych od tych państw, nie pozostała bez wpływu na problematykę ich relacji i sposób, w jaki je skomponowano (Gosk 198). Mogłoby się wydawać, że na podobnej zasadzie historyczna kolonialna zależność ziem ukraińskich od Polski i silne nacechowanie tych terenów polskimi mitami narodotwórczymi uczyni projekt pisania polskich reportaży o Ukrainie niemożliwym. W tym sensie niemożliwym, że perspektywa dawnych relacji polsko-ukraińskich, status ex-kolonizatora oraz wiążące się z nim roszczenie pozycji eksperta przysłaniałyby skutecznie obraz współczesnej Ukrainy. W tym przypadku zaważyło jednak, jak się wydaje, co innego. Dziesięciolecia funkcjonowania Ukraińców w formacji ZSRR oraz homogenizujące mechanizmy przedstawiania "narodu radzieckiego” na zewnątrz sprawiły, że niepodległa Ukraina i jej mieszkańcy stali się dla Polaków po 1991 roku na nowo odkrywanym fenomenem. W dodatku silne napięcia społeczne, które wstrząsają tym młodym krajem regularnie od początku XXI wieku, sprawiają, że wielu polskich reportażystów (mam na myśli głównie Wiesława Romanowskiego, Piotra Pogorzelskiego, Piotra Pieniążka, Zbigniewa Parafianowicza, Michała Potockiego, Grzegorza Szymanika, Julię Wizowską, a także Katarzynę Kwiatkowką-Moskalewicz) opatruje swoje teksty bogatym materiałem faktograficznym i skupia się na tłumaczeniu bieżącej rzeczywistości społeczno-politycznej, skrywając za relacją swój autorski głos. Szczerek podejmuje tymczasem wyzwanie wyjścia przed fakty i pozwala, by przedustawne okoliczności kierowały jego narracją $\mathrm{w}$ większym stopniu aniżeli bieżące wydarzenia polityczne. Tatuaż z tryzubem z 2015 roku to zbiór tekstów o Ukrainie w przededniu i w dobie rewolucji godności, jednak to nie protesty społeczne stanowią główną oś fabularną książki, w której obok reportażu pojawiają się także elementy eseju historycznego, a nawet autobiografii. Szczerek pragnie zachować status zewnętrznego obserwatora i komentatora 
tak bardzo oczywistego w literaturze podróżniczej, a tak bardzo wikłającego autora $\mathrm{w}$ działania o charakterze opresyjnym, związane z przemocą przedstawiania. Świadomość tego, że żadna podróż nie jest niewinna, nie musi wszakże i nie powinna chyba prowadzić do rezygnacji z pisania ${ }^{5}$. Czy fakt, że Szczerek zaczął od siebie i najpierw wydał książkę o, nazwijmy to tak, ekspiacyjnym charakterze, oznacza ex officio, że może być bardziej krytyczny w stosunku do sytuacji ukraińskiej? Lub inaczej: czy fakt ten usuwa automatycznie wszelki paternalizm, czający się w krytyce i podpowiadanych rozwiązaniach? Trudno odpowiedzieć jednoznacznie na te pytania, można natomiast spróbować obronić tezę, że w Tatuażu z tryzubem pisarz rezygnuje z egzotyzacji Ukrainy i wybiera strategię jej udomawiania. Może być ona rozumiana jako redukcja zależnościowego napięcia, wynikającego właśnie z tego, że ukraińską rzeczywistość opisuje i komentuje polski reportażysta. Strategia opiera się na trzech zasadach: a) racjonalizowania postaw opisywanych ludzi - Szczerek komentuje nielogiczne, wydawać by się mogło, czyny swoich bohaterów najczęściej poprzez stwierdzenia "wcale mnie to nie zdziwiło", „rozumiałem ich" lub „na ich miejscu zrobiłby to samo"; b) szukania analogii między sytuacją polską a ukraińską - pisarz podkreśla niejednokrotnie, że Polska i Ukraina należą do wspólnej, "postapokaliptycznej” - jak ją nazywa - rzeczywistości i wiele jej aspektów można znaleźć równie dobrze po obu stronach granicy:

Czasem mijałem stare polskie cmentarzyki. Były dokładnie takie same jak stare cmentarze niemieckie na Dolnym Śląsku, w Lubuskiem czy na Pomorzu. No, może krzyże bardziej toporne, może więcej betonu, a mniej kamienia, może liternictwo nie aż tak koronkowe. Ale chodziło o to samo: kruszejące nagrobki z martwymi nazwiskami sterczące pomiędzy dzikimi chaszczami... (Szczerek 2015: 7).

c) wprowadzania wątków autobiograficznych, które mają zaświadczyć, że samemu autorowi bliskie jest przygnębiające doświadczenie życia w kraju po omacku poszukującym swej formy i zapatrzonym w zachodnie, nie zawsze kompatybilne z miejscową tradycją wzorce. Wędrówki po ukraińskich miastach odsyłają niekiedy pisarza do rodzinnych stron:

Połtawa przez większość czasu swojego istnienia leżała w Rosji i wyglądała jak typowe rosyjskie imperialne miasto. Kamienice niskie, ulice obsadzone drzewami. Ładnie tu było [...], ale tego ładnego nie było zbyt dużo. Ledwo się zaczęło, a już się kończyło. Znałeś skądś tę architekturę i długo nie mogłem się połapać, o co chodzi, aż w końcu zrozumiałem: Połtawa przypominała mi inne dawne rosyjskie gubernialne miasto: Radom ${ }^{6}$ (Szczerek 2015: 179-180).

5 Później, w Międzymorzu, Szczerek napisze: „To jest książka podróżnicza. To będzie książka o podróżach i wrażeniach. Komu się to nie podoba, niech odłoży ją już teraz" (Szczerek 2017: 9).

6 Radom to miasto rodzinne Szczerka. 
Powyższa strategia zawiera w sobie niebezpieczeństwo ujrzenia już nie Mordoru, jak w przypadku skrajnej egzotyzacji w gonzo, ale po prostu drugiej Polski. Do zbyt "radykalnego" udomowienia Ukrainy w Tatuażu z tryzubem jednak nie dochodzi, a Szczerek w ciekawy sposób pokazuje, jak ukraiński projekt narodowy, funkcjonujący przez całe wieki w sytuacji opresyjnego kolonializmu i nabierający przez to cech regresywnych i ekskluzywnych, próbuje zagospodarować sobą otrzymaną po 1991 roku ogromną przestrzeń geograficzną: „Państwo ukraińskie nie było w stanie nadać przestrzeni własnej formy, nie umiało jej apdejtować, więc opanowywało ją symbolicznie" (Szczerek 2015: 6). W wielkich miastach ukraińskość inercyjnie spychana jest często do rustykalnych form jej manifestacji, między innymi poprzez popularne knajpy z tradycyjnym ukraińskim jedzeniem, stylizowane na wnętrza chłopskich chat (Szczerek 2015: 48). Zamalowywanie przestrzeni publicznej na żółto-niebiesko jest bez wątpienia próbą zaklinania rzeczywistości i infantylną metodą podkreślania jej przynależności do tej, a nie innej wspólnoty politycznej. Z drugiej strony cyrkulacyjny charakter relacji przestrzeni i człowieka pokazuje, że te administracyjne zabiegi nie są pozbawione tożsamotwórczych efektów. Szczerek przyznaje, że stanowi to dla niego pewną zagadkę, dlaczego ukraińskość (poza zachodnią częścią kraju) nie transformowała się ostatecznie w wariant rosyjskości, tak jak śląskość w wariant polskości, bawarskość w wariant niemieckości, a prowansalskość - francuskości (Szczerek 2015: 40). Reportażysta wdaje się jednocześnie w polemikę z Mykołą Riabczukiem, twierdząc, że nie przekonują go tezy ukraińskiego publicysty na temat wielkoruskiego kolonializmu, blokującego procesy tworzenia się ponadregionalnej wspólnoty (Szczerek 2015: 40). Abstrahując od samej dyskusji, której rozwinięcie skutkowałby przynajmniej kilkoma nowymi tekstami, warto zaznaczyć, że stanowisko Szczerka wiąże z tym, że dla tego pisarza pamięć indywidualna i krótsza perspektywa historyczna są ważniejsze niż pamięć zbiorowa, której treści pozostają pod przemożnym wpływem teraźniejszości danej wspólnoty (Saryusz-Wolska, Traba 349). Między innymi z tej właśnie przyczyny w Przyjdzie Mordor... Szczerek neguje monolityczność polskiej wspólnoty narodowej ponad granicami. W przypadku Ukrainy Wschodniej jego stanowisko najlepiej oddają fragmenty poświęcone jednemu z miast obwodu charkowskiego:

Mój Boże, cóż było w Iziumie. Nic nie było w Iziumie. No, ładna katedra stała, malowana na jasnobłękitno, a pod katedrą trochę babć w chustkach, kilku dziadków z paznokciami jak skórki pomarańczy. Ta katedra to był znany przykład kozackiego baroku. Obok katedry stały jakieś budy z białej cegły i widać było, że $\mathrm{w}$ tym świecie wcale nie chodzi o żadną katedrę w kozackim baroku, tylko właśnie o te budy w białej cegle.

To te budy w białej cegle pokazywały, czym naprawdę jest ten świat. Biała cegła ciągnęła się jak Izium długie i szerokie, jak Słobodszczyna długa i szeroka, jak Ukraina i Rosja długie i szerokie, jak długa i szeroka była Radziecja i jak długa i szeroka jest Poradziecja (Szczerek 2015: 185). 
Zdaniem Szczerka przestrzeń, w której człowiek dojrzewa, ma na niego o wiele bardziej formacyjny wpływ aniżeli posiadająca spekulatywny charakter pamięć zbiorowa. Dlatego niezależnie od tego, czy pisarz opisuje pobyt polskich żołnierzy w Kijowie w 1920 roku, najazdy Kozaków na Stambuł czy też stacjonowanie zachodnioukraińskich żołnierzy na Donbasie, za każdym razem stara się on uchwycić, jakie wrażenie musiała wywrzeć na nich obca im przestrzeń, którą konfrontują $\mathrm{z}$ indywidualnymi powidokami, czyli pamięcią o przestrzeniach, w których się wychowali.

Co do pamięci zbiorowej, to $w$ reportażach Szczerka jej trubadurami stają się przypadkowo spotkani na dworcach, przejściach granicznych, w knajpach czy na przystankach autobusowych bohaterowie, których można by nazwać też postapokaliptycznymi historiozofami. Wygłaszają oni pełne aberracji tyrady o starożytnym złotym wieku czy misji dziejowej swojego narodu, obnażając automatycznie kompensacyjną funkcję opowiadanych historii.

Konflikt militarny pomiędzy Rosją a Ukrainą, jak się wydaje, wyhamował ostatecznie proces zlewania się wschodniej ukraińskości w rosyjskość. Nowa sytuacja stymuluje więc do poszukiwania rozwiązań, które będą odpowiedzią na jej potrzeby. Jak pisze Szczerek: „Kijów tworzy nową tożsamość, i kto wie, czy nie będzie to jedna z najbardziej oryginalnych i ciekawych tożsamości w Europie" (Szczerek 2015: 261).

\section{Ukraina w mozaice regionalnych fantazmatów narodowych}

Wydane w 2017 roku Międzymorze to, jak trafnie zauważył Kalin, „przewodnik po pseudowspólnocie Europy Środkowej, albowiem okazuje się, że właściwie jedynym konceptem łączącym mozaikę narodów w tym wirtualnym Międzymorzu jest separująca je idea narodowa" (Kalin 83). Sama komparatystyka snów o potędze w stylu "Let's make Poland (Hungary, Slovakia, Macedonia etc.) great again” demaskuje iluzoryczność każdego z nich oraz ukryty naśladowczy charakter takich mrzonek, podobnie jak naśladowcze jest samo hasło. Odbywająca się w Europie Środkowej ucieczka od Zachodu zdaniem Szczerka przypomina „bieg lemingów” (Szczerek 2017: 343), który skończy się albo ponownym zwycięstwem zachodnich idei na tych terenach, albo stopniowym ich popadaniem $\mathrm{w}$ rosyjską strefę wpływów.

Reportażysta typologizuje i różnicuje wewnętrznie Europę Środkową i Wschodnią najczęściej za pomocą przestrzeni, będącej rezultatem społecznego wytwarzania, której dowierza bardziej aniżeli rewelacjom wyciągniętym na powierzchnię z rezerwuarów pamięci zbiorowej. Jednym z narzędzi opisu wspólnot narodowych, zamieszkujących umowny region Międzymorza, jest obserwacja, w jaki sposób dana wspólnota potrafi koegzystować z zastanym środowiskiem architektonicznym, 
przy czym punktem odniesienia jest zazwyczaj model niemiecki. Posttotalitarny okres opisywany w reportażach nazywany jest najczęściej postapokalipsą. Postapokalipsa to według Szczerka czas, w którym „świat ograniczył się do starzenia, do zużywania się" (Szczerek 2013: 12). Bezkształtności, niemocy w odnalezieniu i powrocie do formy reportażysta poświęca wiele uwagi. Cezurą początkową okresu postapokalipsy jest zasadniczo rozpad bloku socjalistycznego, co nie oznacza, że wcześniej dbano tu o formę jakoś szczególnie. Architektura, która powstała w większości w czasach dominacji w tym regionie innych etnosów, rozpada się, ale jednocześnie zaczyna żyć własnym życiem na kształt zapuszczonego ogrodu. Szczerek pisze, że tak jak las obrasta mchem i jemiołą, tak tutaj domy obrastają budami, przybudówkami, płytami pliśniowymi, nawet kawałkami billboardów, które montowane są zamiast ścian i dachów (Szczerek 2013: 12). Ta postapokaliptyczna przestrzeń, która wiecznie traci formę i nie może nabrać nowej, domaga się odpowiedniej toponimii. I taką toponimię Szczerek tworzy, używając określeń jak Poradziecja, Posowietia, a dla patetycznie określanych w czasie PRL-u Ziem Odzyskanych wymyśla prostą nazwę Poniemiecja. Czasami pisarz odwołuje się do egzonimów tworzonych w swoim czasie przez zachodnich autorów, dzięki czemu pojawiają się takie określenia jak: Rurytania, Elbania, Borduria, Krakozja, Molwania oraz Mordor. Skłonność do alternatywnej toponimii pełni u Szczerka nie tylko funkcje estetyczne. Konsekwentnie nazywając zachodnie obwody Ukrainy Hałyczyną, symbolicznie uwalnia ten obszar od odsyłającej wciąż ku mitycznej wielokulturowości nazwy Galicja i daje mu szansę na nową tożsamość. Czasami jednak pisarz sam wpada w pułapkę toczącej się na Ukrainie walki ideologicznej. Dzieje się tak przypadku nominacji mieszkańców Donbasu. Rezygnując ze stygmatyzującego przymiotnika donieccy (określającego zazwyczaj mieszkańców nie tylko miasta, ale i całego regionu), pisarz wybiera etnonim Donbasyci, który - jak się okazuje - jest neologizmem utworzonym przez twórców nowej polityki historycznej nieuznawanych republik DNR i LNR, mającym na celu podkreślenie odrębności etnicznej mieszkańców regionu (Abibok 2018).

Szczerka-reportażystę fascynują przestrzenie liminalne. Granice, krańce, niezliczone końce światów. Stara się zarejestrować, jak pisze, „banalną a niepojętą pograniczną codzienność" (Szczerek 2017: 245) i uchwycić sposób, w jaki jeden świat przelewa się $\mathrm{w}$ drugi, jak w ostatnim kawałku danego państwa manifestuje się już to jego niemieckość, już to polskość, litewskość, słowackość etc. Przykładem tego jest Bogatynia, którą Szczerek nazywa ostatnim bastionem polskiego polbruku i szyldozy (Szczerek 2017: 124). Przekraczając przejście graniczne w Medyce, rozważa, jak wyglądałaby ta miejscowość, gdyby w 1948 roku nie doszło do korekty granicy między Polską a ZSRR: „Domy by były trochę inne. Mniej by było tynku baranka, mniej blachodachówki, więcej eternitu. Kostka brukowa byłaby inna. [...] Krawężniki byłyby pomalowane na rażący biały kolor" (Szczerek 2015: 60). Czasem jednak konsekwencje mogłyby być bardziej doniosłe. Odwiedzając na cmentarzu 
w przygranicznej Łomnej grób Romana Motyczaka, ukraińskiego żołnierza, który zginął w walkach pod oddalonym o tysiąc kilometrów od rodzinnej wioski Iłowajskiem, Szczerek wyznaje, że długo nie dawało mu spokoju pytanie o to, kim byłby dzisiaj Roman Motyczak, gdyby w 1951 roku któremuś z decydentów drgnęła ręka i nie doszłoby do kolejnej wymiany terytoriów pomiędzy PRL a ZSRR. Być może Motyczak byłby dziś emigrantem w Londynie, a być może szukałby szczęścia w Warszawie? Donbas byłby dla niego w każdym razie bardzo odległym światem. Refleksja ta ewokuje u pisarza kolejne pytania:

Jak to jest dać się zabić za coś, co jest częścią wielkiego wyobrażenia, bo wszystkie te narodowe konstrukcje są wielkimi wyobrażeniami, złudzeniami, które w pewnym momencie stają się rzeczywistością, tak oczywistą, tak namacalną jak kula, która w ich imieniu leci i rozrywa skórę, kości, mięśnie, narządy wewnętrzne (Szczerek 2015: 317).

Ukrainie w Międzymorzu reportażysta poświęca stosunkowo niewiele miejsca, czego - jak się wydaje - nie należy tłumaczyć jedynie faktem dedykowania jej poprzednich książek. Zwróćmy uwagę, że korzenie problemów, z którymi zmaga się współczesna Ukraina, nie mają wiele wspólnego z rozkwitem konserwatywnych idei narodowych w pozostałych państwach regionu. Ten kraj nie ucieka od Zachodu, jak robią to liczni jego sąsiedzi. Ukraina nie do końca wpisuje się więc w mozaikę Międzymorza, choć naturalnie jej doświadczenie może stanowić memento dla całej Europy Środkowo-Wschodniej, przypominając jej, że zagrożenia konfliktem militarnym nie należy traktować czysto hipotetycznie.

„Ukraińska trylogia” Szczerka jest zatem wielopoziomowym spojrzeniem na współczesność naszego wschodniego sąsiada i ważnym głosem zarówno w polskim dyskursie ukrainoznawczym, jak i w wewnętrznej debacie społecznej w Polsce. Dla krytyków i badaczy literatury twórczość radomskiego autora stanowi swego rodzaju wyzwanie. Styl jego wypowiedzi bywa bowiem często prowokacyjny, jednak fakt ten nie może przysłaniać głębokiej wrażliwości postkolonialnej, którą niewątpliwie obdarzony jest pisarz. Czytając niektóre fragmenty reportaży, ulegamy pokusie oskarżenia autora o folgowanie „bydlęcemu mechanizmowi każącemu każdego oddalonego od centrum traktować z pobłażaniem" i dopiero w drugim odruchu orientujemy się, że akt oskarżenia pisarza jest jednocześnie cytatem z jego książki (Szczerek 2017: 195).

\section{BIBLIOGRAFIA}

Abibok, Julia. „Polityka tożsamości samozwańczych republik na wschodzie Ukrainy”. 2018. Web. 16.01.2019 <https://www.osw.waw.pl/pl/publikacje/komentarze-osw/2018-0606-/polityka-tozsamosci-samozwanczych-republik-na-wschodzie> 
Adamczewska, Izabella. „Wariacje na temat pewnego paktu. O dziennikarstwie gonzo”. Łódzkie Studia Literaturoznawcze 3 (2014). S. 187-204.

Bakuła, Bogusław. Oblicza autotematyzmu (autorefleksyjne tendencje w polskiej prozie po roku 1956). Poznań: WiS, 1991.

Boruszkowska Iwona, Pieczek Urszula. „I opowiadać sobie wszystkie te ruskie hardkorowe historie...”. 2013. Web. 16.01.2019. <http:// popmoderna.pl/\%E2\%80\%9Ei-opowiadac-sobie-wszystkie-te-ruskie-hardkorowe-historie-przyjdzie-mordor-i-nas-zje/>

Cobel-Tokarska, Marta. „«Strasznie i pięknie». Ukraińskie podróże młodych Polaków”. Sąsiedztwa III RP. Ukraina - zagadnienia społeczne. Red. M. Dębicki, J. Makaro. Wrocław: Gajt, 2015. S. 198-225.

Dąbrowska, Justyna E. „Obraz państwa postapokaliptycznego w prozie Ziemowita Szczerka”. Annales Universitatis Mariae Curie-Skłodowska. Sectio FF, Philologiae 34 (2016). S. 187-199.

Gosk, Hanna. Wychodzenie z "cienia imperium”. Wątki postzależnościowe w literaturze polskiej XX i XXI wieku. Kraków: Universitas, 2015.

Janiec-Nyitrai, Agnieszka. Zobaczyć na nowo. Podróże literackie Andrzeja Stasiuka, Krzysztofa Vargi i Ziemowita Szczerka. Budapest: Budapest Főváros XIII. Kerületi Lengyel Nemzetiségi Önkormányzat, 2018.

Kabaczij, Roman. Istorii z krainy Hirshykh. 2014. Web. 16.01.2019. <http://litakcent.com/2014/09/24/ istoriji-z-krajiny-hirshyh/>

Kalin, Arkadiusz. „Polska szkoła zmyślania - literacki reportaż podróżniczy. Podróże z Mordoru do Międzymorza Ziemowita Szczerka". Forum poetyki 11-12 (2018). S. 64-85.

Kwiatkowska-Moskalewicz, Katarzyna. Zabić smoka. Ukraińskie rewolucje. Wołowiec: Czarne, 2016.

Levokova, Anastasiia. Shukachi skhidnoho hardkoru, abo Slova Petra pro Pavla... 2014. Web. 16.01.2019. <https:// zbruc.eu/node/26136>

Literatura 2013. Nominowany Ziemowit Szczerek. 2013. Web. 16.01.2019. <https://www.polityka.pl/tygodnikpolityka/kultura/paszporty/1563357,1,literatura-2013-nominowany-ziemowit-szczerek. read>

Orekhov, Vladimir. „Otvetnaya literaturnaya retseptsiya kak ob"yekt imagologii”. Literaturna komparativistika 1 (2015). S. 99-112.

Pieniążek, Paweł. Wojna, która nas zmieniła. Warszawa: Wydawnictwo Krytyki Politycznej, 2017.

Parafianowicz Zbigniew, Potocki Michał. Wilki żyja poza prawem. Jak Janukowycz przegrał Ukrainę. Wołowiec: Czarne, 2016.

Pogorzelski, Piotr. Barszcz ukraiński. Gliwice: Helion, 2014.

Romanowski, Wiesław. Przystanek wolność. Kraków: Wydawnictwo literackie, 2007.

Rybicka, Elżbieta. Geopoetyka. Przestrzeń i miejsce we wspótczesnych teoriach i praktykach literackich. Kraków: Universitas, 2014.

Saryusz-Wolska Magdalena, Traba Robert, red. Modi memorandi: Leksykon kultury pamięci. Warszawa: Wydawnictwo Naukowe Scholar, 2014.

Szczerek, Ziemowit. Międzymorze. Warszawa: Agora SA, Czarne, 2017.

Szczerek, Ziemowit. Przyjdzie Mordor i nas zje, czyli tajna historia Stowian. Kraków: Korporacja Ha!art, 2013.

Szczerek, Ziemowit. Tatuaż z tryzubem. Wołowiec: Czarne, 2015. 
Szydłowska, Joanna. „O pożytkach z podglądania marginesu, czyli po co centrum peryferie. Egzotyzacja świata w prozie reportażowej Ziemowita Szczerka (Przyjdzie Mordor i nas zje, czyli tajna historia Stowian)". Centra-peryferie w literaturze polskiej XX i XXI wieku. Red. W. Browarny, D. Lisak-Gębala, E. Rybicka. Kraków: Universitas, 2015. S. 375-387.

Szymanik Grzegorz, Wizowska Julia. Po pótnocy w Doniecku. Warszawa: Agora SA, 2016.

Żyrek-Horodyska, Edyta. „Od amerykańskiego snu Thompsona po ukraiński Mordor Szczerka. Estetyzacja świata w duchu gonzo". Konteksty kultury 2 (2017). S. 217-232. 
